\section{RECORD OF PoECILOTHERIA REgALIS POCOCK, 1899 FROM NALLAMALA HILLS, EASTERN GHATS, ANDHRA PRADESH}

\author{
K. Thulsi Rao ${ }^{1}$, M. Prudhvi Raju ${ }^{1}$, I. Siva Rama Krishna ${ }^{1}$, \\ S.M.M. Javed ${ }^{1}$, Manju Siliwal ${ }^{2}$ and C. Srinivasulu ${ }^{3}$
}

${ }^{1}$ ERM Labs, Nagarjunasagar Srisailam Tiger Reserve, Srisailam, Kurnool District, Andhra Pradesh 518102, India

${ }^{2}$ Corresponding author; Wildlife Information \& Liaison Development Society, 29-1, Bharathi Colony, Peelamedu, Coimbatore, Tamil Nadu 641004 India

${ }^{3}$ Department of Zoology, Osmania University, Hyderabad, Andhra Pradesh 500007, India

Email: manjusiliwal@rediffmail.com

(web supplement 1668i)

The Nallamala $\left(15^{\circ} 20^{\prime}-16^{0} 31^{\prime} \mathrm{N} \& 78^{0} 30^{\prime}-80^{\circ} 10^{\prime} \mathrm{E}\right)$ is a group of low hill ranges in the central part of Eastern Ghats. It is an unbroken chain of rugged hills spread over $7,640 \mathrm{~km}^{2}$ (Srinivasulu $\&$ Nagulu, 2002). The vegetation is typically of southern tropical dry deciduous and southern tropical moist deciduous forest types intermingled with scrub (Champion \& Seth, 1968). The climate is generally hot and dry with temperature rising up to $43^{\circ} \mathrm{C}$ to $45^{\circ} \mathrm{C}$ during May and dips down to $8^{\circ} \mathrm{C}$ in December. Average rainfall in this region is between 900 to $1,000 \mathrm{~mm}$. It includes two protected areas, namely the Nagarjuanasagar Srisailam Wildlife Sanctuary and the Gundla Brahmeshwaram Metta Wildlife Sanctuary.

Surveys were carried out in selected locations of Nagarjunasagar Srisailam Tiger Reserve) from December 2001 onwards to document the faunal diversity. During the survey we sighted Poecilotheria regalis Pocock, 1899 in different locations. To study these large bodied spiders we basically relied on indirect evidence including exuvia and silk lined burrows/holes on tree trunks.

The Regal Parachute Spider Poecilotheria regalis Pocock, 1899 (Images $1 \& 2^{\mathrm{w}}$ ) is arboreal and endemic to India. It was first described from Arakonam, North Arcot District, Tamil Nadu. Distribution includes many previously published localities in the Western Ghats, the Eastern Ghats and other localities from recent studies/sightings (Pocock, 1900; Molur et al., 2004). Although first reported from the Eastern Ghats, it was widely collected from the Western Ghat localities from Mumbai to Palakkad. Recent surveys on the large bodied spiders carried out by us (MS) reveal its presence from hitherto unreported localities in southern India indicating its widespread distribution.

The presence of Poecilotheria regalis Pocock, 1899 had been noted from four different localities both from Farahabad Plateau in Mahbubnagar District and Srisailam Plateau in Kurnool District. Three specimens and three exuvia were collected between December 2001 and August 2003.

One male in alcohol, 1.viii.2002, Thummalabailu, coll. Siva Rama Krishna and S.M.M. Javed, ERM/SPI/29A, ERM Labs Museum, Sunnipenta; one male, 16.ix.2002, tea shop, Shikharam, coll. Siva Rama Krishna and S.M.M. Javed, ERM/SPI/29B; one male, 7.viii.2003, Shikharam Temple, Shikharam, coll. Thulsi Rao and team, ERM/SPI/29C. Morphometric range of the specimens is given in Table 1.

We also collected three exuvia of large bodied spiders during the study period that were confirmed to be that of $P$. regalis Pocock, 1899. Of these two were found in the wild, namely near Biarapur Cheruvu, District Mahbubnagar (Farahabad Plateau) and near Sunnipenta, District Kurnool (Srisailam Plateau). The third exuvia is from the third voucher specimen (ERM/SPI/29C) collected from Shikharam that had been kept in captivity.

$P$. regalis can easily be distinguished from rest of the known species of this genus by the presence of the broad reddish band on the ventral side of the abdomen (Image 2). Males of this species are usually frequently sighted during the rainy season when they wander in search of females to mate (Molur et al., 2004). While wandering the males enter nearby human dwellings. All the three specimens encountered during the present study are males and usually immediately after the rains. ERM/SPI/29A was found at the base of Zizyphus oenophila near Thummalabailu. There was no proper tree hole in which it could stay for long and there were no evidence of any web in any of the holes in the adjacent trees. ERM/SPI/29B, found on the table of a teashop in Shikharam, was collected in the morning after rain. The third specimen, also from Shikharam, was noticed on the temple wall.

\section{ReFERENCES}

Champion, H.G. and S.K. Seth (1968). A Revised Survey of the Forest Types of India. Government of India Press, New Delhi, 404pp. Molur, S., B.A. Daniel and M. Siliwal (2004). Distribution of the Regal Parachute Spider Poecilotheria regalis Pocock, 1899 in India. Zoos' Print Journal 19(10):

Pocock, R.I. (1899). The genus Poecilotheria: its habits, history and species. The Annals and Magazine of Natural History (7)3: 82-96.

Pocock, R.I. (1900). The Fauna of British India, Arachnida. Taylor and Francis, London, 279pp.

Smith, A. and P. Kirk (2001). A field Guide on the Theraphosid Spiders of Indian and Sri Lanka particularly the genus Poecilotheria. (Unpublished).

Srinivasulu, C. \& V. Nagulu (2002). Mammalian and avian diversity of the Nallamala Hills, Andhra Pradesh, India. Zoos' Print Journal 17(1): 675-684.

Table 1. Morphometry of P. regalis from Nallamala Hills.

\begin{tabular}{llll}
\hline Particulars & \multicolumn{3}{c}{ Measurement (in mm) } \\
& ERM/SPI/29A & ERM/SPI/29B & ERM/SPI/29C \\
\hline Cephalothorax & & & \\
Length & 21.0 & 16.5 & 18.5 \\
Width & 20.0 & 14.0 & 18.0 \\
Sternum & & & \\
Length & 11.0 & 7.0 & 9.5 \\
Width & 8.5 & 6.0 & 6.0 \\
Leg I Length & 100.0 & 81.5 & 86.5 \\
Leg II Length & 88.5 & 70.0 & 77.0 \\
Leg III Length & 73.5 & 58.5 & 66.5 \\
Leg IV Length & 89.5 & 73.0 & 80.0 \\
Palp Length & 74.0 & 42.0 & 49.5 \\
Abdomen & & & \\
Length & 23.0 & 18.0 & 22.5 \\
Width & 19.0 & 9.0 & 10.5 \\
Total Body Length & 44.0 & 34.5 & 48.0 \\
Leg Formula & $1>4>2>3$ & $1>4>2>3$ & $1>4>2>3$ \\
\hline
\end{tabular}

Stidulatory organs in form of setae and thick hair present between maxillae and chelicerae

w See Images $1 \& 2$ on the web supplement at www.zoosprint.org 